\title{
Cost Shares and Factor-Cost Ratios in Owner-Built Incremental Housing in Dar Es Salaam, Tanzania
}

\author{
*Samwel Alananga Sanga' and Charles Lucian²
}

Published online: 31 July 2016

To cite this article: Samwel Alananga Sanga and Charles Lucian. (2016). Cost shares and factor-cost ratios in owner-built incremental housing in Dar Es Salaam, Tanzania. Journal of Construction in Developing Countries, $21(1)$ : 113-130. doi: 10.21315/jcdc2016.21.1.6

To link to this article: http://dx.doi.org/10.21315/jcdc2016.21.1.6

Abstract: The adoption of incremental owner-built techniques in housing construction relies on the associated lower cost compared to developer-built approaches. The mechanism that lowers cost is however, not obvious. This study is based on survey data that were collected using questionnaires which were distributed to 200 respondents in Dar es Salaam, Tanzania with response rate of $22.5 \%$. The analysis results, based on descriptive statistics and regression analysis indicate that an incremental house-builder targeting an additional bedroom incrementally spends $28 \%$ lower annual construction cost and each additional square meter built, is associated with $0.4 \%$ lower cost. However, such lower cost comes at a 5\%-10\% longer completion time. These observations suggest that spreading costs over time reduces construction cost through multiple cost-saving channels opened up by time itself and factor intensity. The intensity of incremental housing construction favours increasing expenditure on labour than capital yielding a $5 \%$ reduction in annual cost but the greatest cost reduction benefit of up to $26 \%$ is realised through increasing expenditure on "capital" with fixed spending on materials during construction.

Keywords: Cost, Factor-cost ratios, Housing, Owner-built housing, Dar Es Salaam

\section{INTRODUCTION}

In developing countries, the majority of housing units are provided incrementally in what is called owner-built housing (Malpezzi and Sa-Aadu, 1996; Mumtaz, 1995). The owner-built incremental housing is adopted partly as a matter of necessity since households have limited less costly alternatives (Majale, Tipple and French, 2012; Siddiqui, 2005; Drummond, Chongo and Mususa, 2013). This lower cost argument has been criticised as it contradicts with the western views on economies of scale (Arvanitis, 2013; Samaranayake, 2012; Boamah, 2010). This paper investigates the impact of key attributes of incremental housing provision in Dar es Salaam in relation to construction cost in order to accord due weights to either arguments. Based on both descriptive and regression analysis, it has been observed that owner-builders targeting bigger houses incrementally often end up with lower annual construction cost but take longer to accomplish their houseownership dream. In terms of factor intensity, it is established that the use of physical and financial capital significantly reduces construction cost. This

\footnotetext{
'Department of Land Management and Valuation, School of Real Estate, Ardhi University, Dar es Salaam, TANZANIA

2Department of Property and Facilities Management, School of Real Estate, Ardhi University, Dar es Salaam, TANZANIA

${ }^{*}$ Corresponding author: samwelalananga@yahoo.com

(C) Penerbit Universiti Sains Malaysia, 2016
} 
observation could be linked to the practices of hiring equipment such as trolleys, concrete mixer and supporting wood (timber) which are common in incremental construction.

A part from informing the wider audience of the structure of owner-built incremental housing cost in Tanzania, this paper argues that preference on such approaches is not only dependent on cost-spread effect of longer construction period (affordability and cheap labour) as it is well known in the literature but also factor intensity where the cost-saving benefits of using factor combinations that have relatively larger cost share of physical/financial capital far outweigh the costsaving advantage of labour cost when both are measured against material cost. This suggests that the practice of shunning away from the use of commercial sources of finance and capital equipment which is common among incremental owner-builders, is only justified under shorter implementation periods. When project costs are spread over a sufficiently longer period of time the cost-saving advantages of using loans and hired capital equipment tend to be larger than the labour cost-saving advantages. This study advocates for a proper regulatory framework to guide the incremental housing supply process especially on the issue of amenities and quality of materials used. Regulating the sector increases construction cost but such rise may not be larger than the intergenerational housing budget constraints of current laxity. Apart from regulating building material quality, housing policies in developing countries need to be aligned towards lengthened loan repayment schedules in order to reach the majority of incremental owner-builders.

\section{HOUSING CONSTRUCTION APPROACHES IN DEVELOPING COUNTRIES}

In developing countries, housing can either be formal or informal (Arvanitis, 2013; Nohn and Bhatt, 2014) but in either case, affordability is a major challenge (Beck, 2012; Drummond, Chongo and Mususa, 2013; Mayank et al., 2012). As a result, formal and conventional developer-built housing approaches are uncommon among the low-income majority (UN-Habitat, 2008; Hoek-Smit, 1998; ShoreBank International, 2011; Neves and Amado, 2014; Samaranayake, 2012). In these countries, housing is mainly provided through owner-built incremental approaches (Gattoni, 2009; Bisiaux, 2014; Beattie, Mayer and Yildirim, 2010; Majale, Tipple and French, 2012; Wakely, 2014). The approaches have evolved over time depending on finances and changing government policies. In the 1970's, site-and-service schemes were common in countries such as Kenya, Tanzania, Sudan, Pakistan and many Latin America countries such as Peru and Mexico under the auspices of the World Bank (Beattie, Mayer and Yildirim, 2010; Malpezzi and Sa-Aadu, 1996; Siddiqui, 2005). Of recent, site-and-service-like projects are implemented by providing developed plot through auction (Siddiqui, 2005; Majale, Tipple and French, 2012).

Incremental housing is naturally fuelled by regulatory laxity which allows plot acquisition and development without following appropriate planning regulations i.e. informal housing (Gattoni, 2009). The third form of incremental housing provision is direct involvement of the government or its subsidiary or NGOs in constructing a core house i.e. an outer frame with/without rooms (Abdel-Kader and Ettouney, 2010) as it was in Khartoum Sudan (Beattie, Mayer and Yildirim, 
2010) or in earthquake stricken Yogakyarta in Indonesia (Maly, Kondo and Shiozaki, 2012). The fourth approach is slum upgrading schemes or regularisation schemes targeting existing housing improvements (van Winssen, 2014; Malpezzi and Sa-Aadu, 1996; Bisiaux, 2014; Gattoni, 2009). The last form is housing transformation executed by altering and/or extending dwellings depending on the availability of funds for the project and the need to minimise costs (Majale, Tipple and French, 2012; Nguluma, 2003; Mukhija, 2014; Nakamura, 2014).

Among the effects of incremental approach is that owner-builders view their houses as not only shelter but also: a basis of social status and prestige (Boamah, 2010; Siddiqui, 2005; Harper, Portugal and Shaikley, 2011; Mehta and Bridwell, 2005), a promise of improved health through more decent sanitation systems and protection from weather, security against violence, vandalism and theft and a route to productivity (Schmidt, 2006), it gives a sense of security, empowerment and hope (Scott, 2012). The consequence of these attachments is to detach housing from economic considerations. Thus it is rare for incremental developers to use their finished houses to access formal finance leading to the western view that the incremental housing approach is a tedious, wasteful and a highly questionable technique for housing provision.

\section{THE INCREMENTAL OWNER-BUILT APPROACH IN TANZANIA}

According to the World Bank (2015a) data, Tanzania's GNI per capital stood at USD 840 in 2013 an equivalent of USD 2,430 in purchasing power parity per annum or Tshs $324,000 /=$ per month based on 2013 exchange rates $(2,430 * 1,600 / 12)$. These data suggest that many people are poor and cannot rely on conventional developer-built housing. These approaches require verifiable and long term sources of finance (Monkkonen, 2009). Like many developing countries (Siddiqui, 2005; Malpezzi and Sa-Aadu, 1996; Greene and Edwardo, 2008; Majale, Tipple and French, 2012; Wakely, 2014), Tanzania adopted the developer-built approach since the 1950's. In the 1960's the National Housing Corporation (NHC) was established and remains the main provider of developer-built housing with a current stock of about 19,000 housing units throughout Tanzania.

Compared to the developed countries, in Tanzania the role of the private sector housing is marginal, principally because of post-independence socialist policies which gave NHC monopoly over housing construction for about 30 years since its establishment in 1962 and the greater percentage of low-income households in the informal sector. NHC estimated housing deficit at 3,000,000 housing units and that housing shortage has since then been growing at 200,000 housing units per annum (NHC-Tanzania, 2010). However these data exclude informal housing provision approaches. The informal housing which is mainly incremental contributes up to $80 \%$ of the total housing stock in major cities of many developing countries (Alagbe, Adewale and Alagbe, 2014; UN-Habitat, 2010).

The origin of urban incremental housing in Tanzania can be traced as far as colonialism. The colonialist neglected Africans' housing issues and applied discriminative policies which allowed segregation of White, Asian and Africans settlements (Kironde, 1995). Thus, black Africans interested in urban life found their own incremental route to housing in settlements that were illegal but within or 
close proximity to towns. These practices continued even in early postindependence, where the government was harsh to these illegal structures (Lim, 1987). Beginning 1970s' to date there have been notable policy changes whereby informal housing has been increasingly recognised as part of the urban built environment. Many housing units considered illegal during colonialism and early post-independence era, are now recognised and legalised (Majale, Tipple and French, 2012; Wakely, 2014; Turner, 1967).

During 1973-1976, Tanzania through the assistance of the World Bank conducted site-and-service schemes in several regions including Dar es Salaam (Mbyopo, 1993). Apart from site-and-service schemes, local authorities have provided developed and undeveloped plots some of which are offered through auctions; a practice adopted in the 20,000 plots project in Dar es Salaam (Siddiqui, 2005; Majale, Tipple and French, 2012; Mwiga, 2011). Further, the government has implemented several squatter upgrading schemes since 1970s (Mbyopo, 1993). Housing transformation has also been observed and documented for Dar es Salaam (Nguluma, 2003; Magigi and Majani, 2006). And lastly, the most recent effort towards recognition of informal owner-built incremental housing in Tanzania includes issuance of residential licenses pertaining to settlements which were declared to be squatters in a case of Mwalimu Omari and Ahmed Baguo vs. Omari Bilal, Civil Appeal 19 of 1996 (MKURABITA, 2008).

\section{COST SHARES AND FACTOR INTENSITY IN INCREMENTAL HOUSING PROJECTS}

The term factor intensity as used in this study refers to the degree at which costs of one factor is higher relative to the other for the same housing unit. In incremental housing, capital equipment can be hired to perform certain processes in the course of construction for which human being cannot perform efficiently. However, in developing countries labour intensity increases as a result of ruralurban migration (Giddings, 2007; Albuquerque, 2012) but productivity declines because of lower technological levels (Wells, 2001; Moavenzadeh and Rossow, 1975). This is supported by data presented in Figure 1 for the case of Tanzania (World Bank, 2015b). Previous studies have suggested that most of the population growth in Tanzania will occur in Dar es Salaam (Mujobu Moyo, Simson and de Mevius, 2010), the focus of this study. 


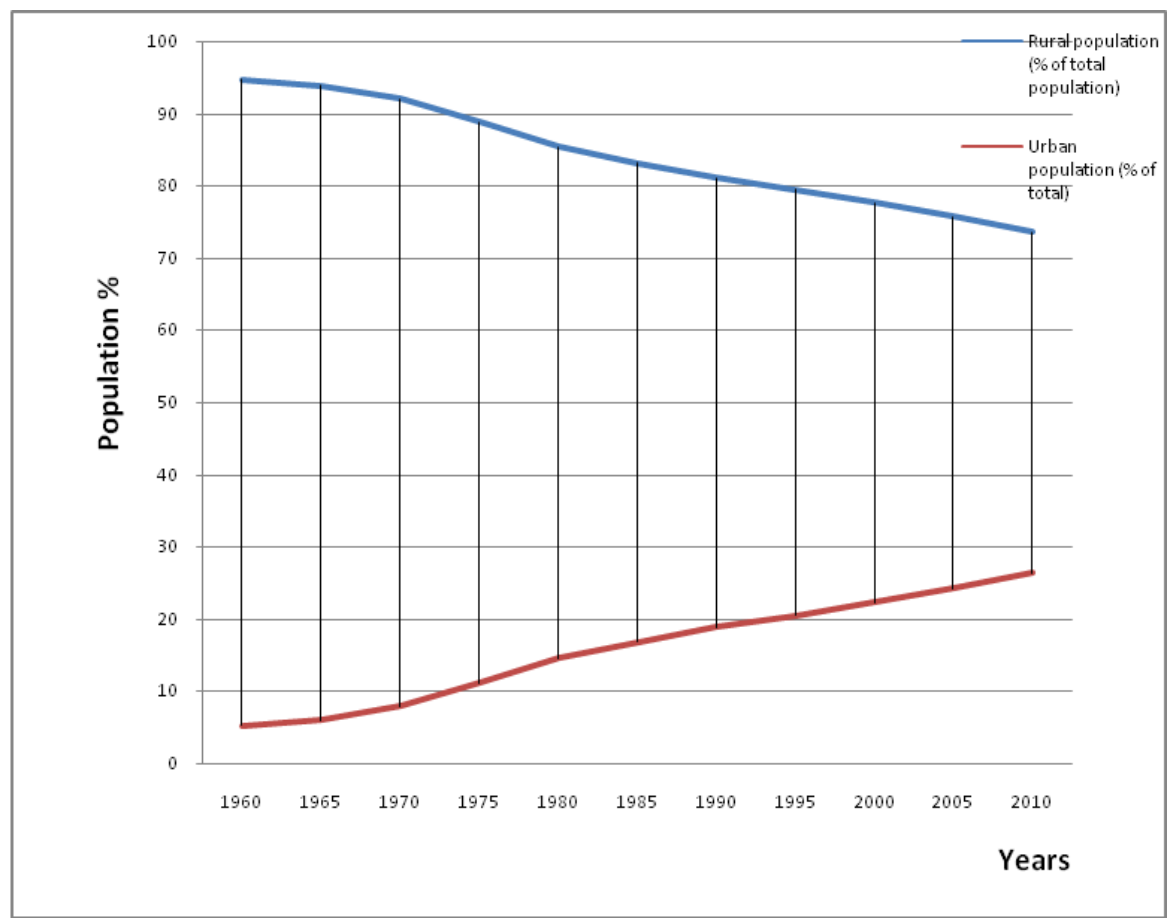

Source: http://data.worldbank.org/indicator/SP.URB.TOTL.IN.ZS

Figure 1. Rural and Urban Population Trends in Tanzania

Studies in Australia and Canada have revealed that prices of both materials and land tend to fluctuate more frequently than labour (Carliner, 2003; New Zealand Productivity Commission, 2012; Taylor, 2012). The breakdown of construction cost in these countries shows that labour cost as a share of total cost ranges between $20 \%-30 \%$ while material cost is around $50 \%$. Land prices are estimated to be $20 \%-25 \%$ of construction cost in the UK (Carliner, 2003). In developing countries, studies on cost shares are however, rare. Arvanitis (2013) estimated hard housing construction cost in Kenya to be $60 \%$ of which $70 \%$ is materials and $30 \%$ is labour. This indicates that material cost is around $42 \%$ which is slightly lower compared to developed countries. In term of plot prices, estimates in Tanzania suggest that, it could be as low as $5 \%$ of construction cost (Makoba, 2009) but, the highest price limit in an inflationary environment could exceed $50 \%$ (Oikarinen, 2009).

\section{RESEARCH METHODOLOGY}

Based on the preceding discussion it can be argued that the quantity of the built space in terms of the number of rooms or size do not only depend on the amount spent on factor-inputs but also the time and preferences of owner-builders. The process through which factors are combined is captured by the factor intensity ratios indicating that construction cost is simply a function of preferences and 
ideas on design features, styles and building materials, time and space (Output) and the processes. This conceptualisation is depicted in Figure 2.

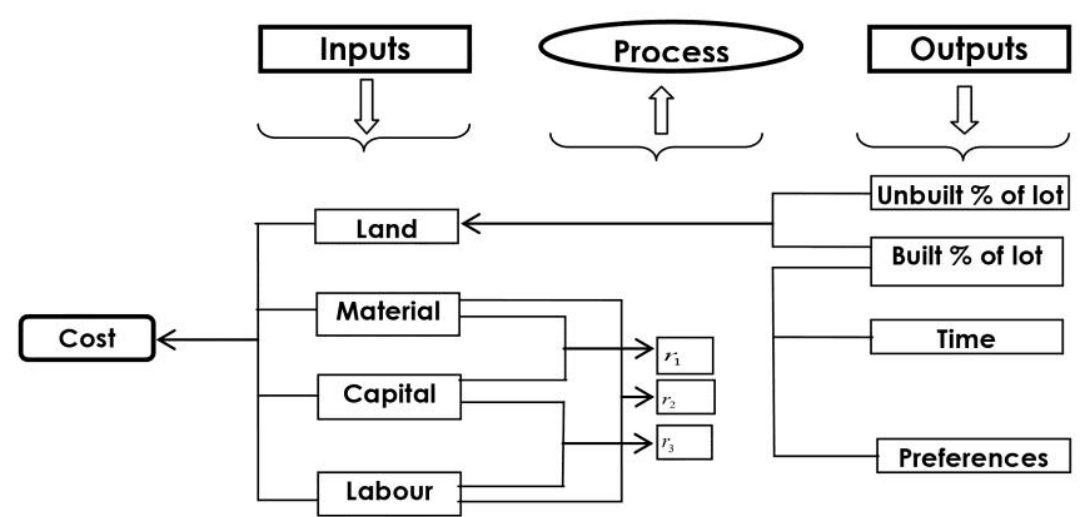

Notes: $r_{1}=$ Capital to material cost ratio; $r_{2}=$ Material to labour cost ratio; $r_{3}=$ Capital to labour cost ratio

Figure 2. A Conceptual Framework for Analysing Factor Intensity and Cost Shares in Relation to Construction Cost

\section{Sample and Data}

To obtain data based on the conceptual framework in Figure 2, this study utilised questionnaires which were administered to 44 house owners in the city of Dar es Salaam, the largest city and commercial capital of Tanzania, between January and March 2013. The questionnaires allowed the respondents to separate the construction of a main house and the extension house resulting into 63 projects. To capture the effect of time under construction each project was attached to the years through which construction was ongoing leading to 369 project years. To obtain the year value for each project, cost figures were spread equally throughout the project implementation period. This adjustment provides a means to weigh each cost figure to the relevant period under which construction was ongoing. To capture the time value of money the average annual construction costs were discounted by the inflation rate for each year. This adjustment acts to stabilise the cost figures leading to more robust results for comparison across projects.

The sampling strategy involved some elements of purposive sampling where 100 government employees were targeted and provided with questionnaires to fill in at their own spare time and another 100 questionnaires were distributed based on a household survey to non-governmental employees. To reach these nongovernmental employees, the researchers visited their houses in wards which were closer to researchers' place of residency or employment. The response rate was $22.5 \%$ of which only two were non-governmental employees. Retrieving questionnaires from non-governmental employees was very difficult thus they are excluded from further analysis. 
Table 1. Descriptive Statistics

\begin{tabular}{|c|c|c|c|c|c|}
\hline & $\begin{array}{c}\text { Number of } \\
\text { Observations }\end{array}$ & Minimum & Maximum & Mean & $\begin{array}{c}\text { Std. } \\
\text { Deviation }\end{array}$ \\
\hline $\begin{array}{l}\text { Natural Log (Ln) of } \\
\text { annual construction } \\
\text { cost }\end{array}$ & 360.00 & 8.30 & 13.84 & 10.82 & 1.25 \\
\hline $\begin{array}{l}\text { Property type main } \\
\text { house }\end{array}$ & 369.00 & 0 & 1 & 0.86 & 0.35 \\
\hline $\begin{array}{l}\text { House type normal } \\
\text { house }\end{array}$ & 369.00 & 0 & 1 & 0.87 & 0.34 \\
\hline $\begin{array}{l}\text { Ln of size of built-up } \\
\text { space }\end{array}$ & 369.00 & 2.20 & 6.40 & 5.06 & 0.60 \\
\hline Number of bedrooms & 361.00 & 1.00 & 6.00 & 3.32 & 0.79 \\
\hline $\begin{array}{l}\text { Labour to material } \\
\text { cost }\end{array}$ & 199.00 & 0.08 & 0.88 & 0.37 & 0.18 \\
\hline Labour to capital cost & 187.00 & 0.04 & 26.67 & 3.96 & 4.66 \\
\hline $\begin{array}{l}\text { Capital to material } \\
\text { cost }\end{array}$ & 187.00 & 0.00 & 2.08 & 0.28 & 0.41 \\
\hline $\begin{array}{l}\text { Duration of housing } \\
\text { construction }\end{array}$ & 369.00 & 1.00 & 20.00 & 6.33 & 5.31 \\
\hline $\begin{array}{l}\text { Duration to home } \\
\text { ownership }\end{array}$ & 369.00 & 1.00 & 21.00 & 9.92 & 5.73 \\
\hline 1998 & 369.00 & 0 & 1 & 0.07 & 0.25 \\
\hline 2000 & 369.00 & 0 & 1 & 0.05 & 0.22 \\
\hline 2002 & 369.00 & 0 & 1 & 0.07 & 0.26 \\
\hline 2004 & 369.00 & 0 & 1 & 0.08 & 0.27 \\
\hline 2006 & 369.00 & 0 & 1 & 0.10 & 0.30 \\
\hline 2007 & 369.00 & 0 & 1 & 0.07 & 0.26 \\
\hline 2008 & 369.00 & 0 & 1 & 0.09 & 0.29 \\
\hline 2009 & 369.00 & 0 & 1 & 0.09 & 0.29 \\
\hline 2010 & 369.00 & 0 & 1 & 0.09 & 0.29 \\
\hline 2011 & 369.00 & 0 & 1 & 0.09 & 0.29 \\
\hline 2012 & 369.00 & 0 & 1 & 0.10 & 0.30 \\
\hline 2013 & 369.00 & 0 & 1 & 0.09 & 0.29 \\
\hline Valid n (list wise) & 176.000 & & & & \\
\hline
\end{tabular}

\section{Variables for Analysis}

The analysis relies on descriptive statistics and regression analysis because the data collected are quantitative and require statistical analysis. Since the researchers wanted to understand the simultaneous effect of predefined variables, it was 
necessary to use multiple regression techniques which allow the simultaneous isolation of the effects of each variable. Given the low response rate, the results of Ordinary Least Squares (OLS) were supported with descriptive statistics to allow critical analysis of the normative statements made in the discussion section. Thus, annual construction cost per square meter (ACC) was regressed onto measures of factor intensity and a number of control variables as shown in Table 1. The model is given by:

$$
A C C=\beta_{0}+\sum_{i=1}^{c} \beta_{i} X_{i}+\sum_{j=1}^{v} b_{1 j} D_{j}+\sum_{k=1}^{13} b_{2 k} Y_{k}+\varepsilon
$$

where, $A C C$ is the annual construction cost per sqm, $\beta_{0}$ is a constant, $\beta_{i}$ is the coefficient for $c$ th factor intensity or control variables $\left(X_{i}\right), b_{1 j}$, is the coefficient for the $v$ th house type and property type dummies $\left(D_{j}\right)$ and $b_{2 k}$ is the coefficient for 13 year dummies $\left(Y_{k}\right)$. Three factor-intensity indicators were included in the regression model each capturing the amount spent (in Tshs) in one factor relative to the other. That is labour-intensity is measured relative to both materials and capital cost while capital intensity is measured relative to material cost only.

\section{Data Analysis and Results}

The summary of the data and variables shown in Table 1 reveals that about $86 \%$ of the projects were for main buildings while $87 \%$ were for single-storey house construction. The duration to home ownership (from plot purchase) ranges between 1-21 years where the houses have one to six bedrooms. Table 3 shows that projects under consideration were implemented from 1990-2013 while the plots were acquired from 1990-2012 (year 1998 in Table 1 represents average values for projects implemented from 1990-1998)

\section{Factor Cost-Shares in Incremental Housing Construction}

A summary of different cost components shown in Table 2 indicates that incremental housing projects allocate the lowest costs to site clearing and site levelling activities while the highest costs are allocated to material cost. This observation is relevant for both single-storey and two-storey projects though in two-storey projects, site levelling cost is not the lowest component. Save only for "other costs" which are 19\% higher for single-storey than two-storey houses, all other cost components are higher for two-storey houses. On average a single-storeysingle-family house would costs about $50 \%$ of the costs associated with the average single-family-two-storey house. The biggest differences in construction costs are observed in terms of site and levelling costs where for the average singlestorey house it is only $10 \%$ of the average two-storey house. The lowest cost differences are observed in terms of plot costs and interest costs where the average construction costs for a single-storey house are $68 \%$ and $60 \%$ of the average two-storey house respectively. 
Table 2. Construction Cost by Components

\begin{tabular}{|c|c|c|c|c|c|c|c|}
\hline \multirow{2}{*}{ Cost Components } & \multicolumn{3}{|c|}{ Single-Storey House } & \multicolumn{3}{|c|}{ Two-Storey House } & \multirow{2}{*}{$\begin{array}{c}\% \text { of Avg. } \\
\text { Single in } \\
\text { Two- } \\
\text { Storey } \\
\text { Costs }\end{array}$} \\
\hline & $\begin{array}{c}\text { Minimum } \\
\text { (Tshs) }\end{array}$ & $\begin{array}{l}\text { Maximum } \\
\text { (Tshs) }\end{array}$ & $\begin{array}{l}\text { Average } \\
\text { (Tshs) }\end{array}$ & $\begin{array}{l}\text { Minimum } \\
\text { (Ishs) }\end{array}$ & $\begin{array}{l}\text { Maximum } \\
\text { (Tshs) }\end{array}$ & $\begin{array}{l}\text { Average } \\
\text { (Tshs) }\end{array}$ & \\
\hline $\begin{array}{l}\text { Total construction } \\
\text { cost }\end{array}$ & $1,980,730$ & $319,066,670$ & $74,478,930$ & $31,540,000$ & $478,600,000$ & $229,082,220$ & 0.33 \\
\hline $\begin{array}{l}\text { Construction cost } \\
\text { per sqm }\end{array}$ & 14,870 & $2,145,450$ & 544,190 & 525,670 & $2,145,450$ & $1,112,270$ & 0.49 \\
\hline Others & 12,000 & $36,000,000$ & $10,687,120$ & $2,000,000$ & $13,000,000$ & $9,000,000$ & 1.19 \\
\hline Interest & 350,000 & $32,351,000$ & $6,014,440$ & $8,000,000$ & $12,000,000$ & $10,000,000$ & 0.60 \\
\hline $\begin{array}{l}\text { Fencing and } \\
\text { pavement }\end{array}$ & 46,750 & $40,000,000$ & $8,654,630$ & $5,000,000$ & $48,000,000$ & $25,375,000$ & 0.34 \\
\hline Supervision & 50,000 & $10,000,000$ & $3,015,880$ & $2,000,000$ & $15,000,000$ & $7,000,000$ & 0.43 \\
\hline Labour & 280,000 & $45,000,000$ & $15,428,780$ & $6,000,000$ & $60,000,000$ & $36,375,000$ & 0.42 \\
\hline Material & $1,186,360$ & $266,666,670$ & $49,343,890$ & $14,000,000$ & $400,000,000$ & $147,375,000$ & 0.33 \\
\hline Electricity & 87,660 & $8,000,000$ & $1.985,020$ & 500,000 & $10,000,000$ & $4,500,000$ & 0.44 \\
\hline Water & 58,000 & $9,000,000$ & $1,795,840$ & $1,500,000$ & $5,000,000$ & $3,583,330$ & 0.50 \\
\hline Hired equipment & 50,000 & $13,363,640$ & $1,607,750$ & 200,000 & $30,000,000$ & $5,612,500$ & 0.29 \\
\hline Site clearing & 9,330 & $1,000,000$ & 167,160 & 40,000 & $1,500,000$ & 692,500 & 0.24 \\
\hline Site levelling & 8,000 & $1,200,000$ & 217,930 & 100,000 & $10,000,000$ & $2,128,570$ & 0.10 \\
\hline Drawing & 17.530 & $7,500,000$ & 542,630 & 500,000 & $2,500,000$ & $1,183,330$ & 0.46 \\
\hline Plot costs & 140,000 & $30,000,000$ & $5,086,270$ & 800,000 & $16,000,000$ & $7,450,000$ & 0.68 \\
\hline
\end{tabular}

Time and Size of Incremental Housing Project

In terms of implementation time and project size, Table 3 shows that single-storey projects were implemented on plots purchased between 1990 and 2012 suggesting the maximum margin of 22 years while two-storey projects plots had been purchased between 2002 and 2011, a margin of nine years. Completion time for single-storey projects is between 2003 and 2014, a margin of 11 years and two-storey projects were completed between 2012 and 2014, a margin of two years. Single-storey projects were implemented on average lot size of $871.29 \mathrm{~m}^{2}$ and the average built space is $153.16 \mathrm{~m}^{2}$ while the average number of bedrooms is three. For two-storey projects the averages for lot size, built space and number of rooms are, $955.38 \mathrm{~m}^{2}, 217.67 \mathrm{~m}^{2}$ and four respectively.

Table 3. Size and Time of Construction Projects

\begin{tabular}{lcccccc}
\hline & \multicolumn{3}{c}{ Single-Storey House } & \multicolumn{3}{c}{ Two-Storey House } \\
\hline & Minimum & Maximum & $\begin{array}{c}\text { Margin in } \\
\text { Years }\end{array}$ & Minimum & Maximum & $\begin{array}{c}\text { Margin } \\
\text { in Years }\end{array}$ \\
\hline $\begin{array}{l}\text { Year of plot } \\
\text { purchase }\end{array}$ & 1990 & 2012 & 22 & 2002 & 2011 & 9 \\
$\begin{array}{l}\text { Year of } \\
\begin{array}{l}\text { construction } \\
\text { completion }\end{array}\end{array}$ & 2003 & 2014 & 11 & 2012 & 2014 & 2 \\
$\begin{array}{l}\text { Plot size at } \\
\text { purchase (sqm) }\end{array}$ & 10.80 & 3000.00 & 871.29 & 72.00 & 2650.00 & 955.38 \\
\hline
\end{tabular}

(continued on next page) 
Table 3. (continued)

\begin{tabular}{lcccccc}
\hline & \multicolumn{3}{c}{ Single-Storey House } & \multicolumn{3}{c}{ Two-Storey House } \\
\hline & Minimum & Maximum & $\begin{array}{c}\text { Margin in } \\
\text { Years }\end{array}$ & Minimum & Maximum & $\begin{array}{c}\text { Margin } \\
\text { in Years }\end{array}$ \\
\hline $\begin{array}{l}\text { House built-up } \\
\text { space (sqm) }\end{array}$ & 9.00 & 600.00 & 153.16 & 60.00 & 315.00 & 217.67 \\
$\begin{array}{l}\text { Number of } \\
\text { bedrooms }\end{array}$ & 1 & 6 & 3 & 3 & 5 & 4 \\
\hline
\end{tabular}

\section{Duration of Incremental Housing Construction}

Table 4 shows that both single-storey and two-storey incremental housing projects were implemented on plots purchased on average about three years earlier. Single-storey house projects take on average about four years to be completed while two-storey projects take about three years.

Table 4. Duration of Construction

\begin{tabular}{|c|c|c|c|c|c|c|}
\hline & \multicolumn{3}{|c|}{ Single-Storey House } & \multicolumn{3}{|c|}{ Two-Storey House } \\
\hline & Minimum & Maximum & Average & Minimum & Maximum & Average \\
\hline $\begin{array}{l}\text { Duration to } \\
\text { construction } \\
\text { start (years from } \\
\text { plot purchase) }\end{array}$ & 0 & 17 & 2.8 & 0 & 7 & 2.9 \\
\hline $\begin{array}{l}\text { Duration under } \\
\text { construction } \\
\text { (years from } \\
\text { construction } \\
\text { start) }\end{array}$ & 1 & 20 & 4.3 & 1 & 5 & 2.9 \\
\hline $\begin{array}{l}\text { Duration to } \\
\text { housing } \\
\text { ownership } \\
\text { (years from plot } \\
\text { purchase) }\end{array}$ & 1 & 21 & 7.1 & 1 & 10 & 6.0 \\
\hline
\end{tabular}

\section{Factor Intensity in Incremental Housing Construction}

Table 5 shows that the material cost for single-storey projects ranges between $27 \%-84 \%$ with an average being $54 \%$ of the overall costs while in two-storey projects, material cost ranges between $44 \%-84 \%$ with the average at $57 \%$. The average land cost is about $5 \%$ and $7 \%$ and the average labour cost is $14 \%$ and $17 \%$ for single-storey and two-storey house projects respectively.

In terms of factor intensity in single-storey projects it can be observed that at the minimum cost, land has the lowest substitutability for materials cost of about one percent. That is each Tshs 1000 spent on materials would require about Tshs 10 spent on land. The maximum degree of substitutability is 0.56 meaning that each Tshs 1000 spent on materials would consume Tshs 560 in the form of land. Similar observation can be made in terms of two-storey projects in which case the 
average degree of substitutability between land and material cost is 0.04 and the average degree of labour to material cost substitution is 0.32 .

Table 5. Factor-Cost Ratios and Cost Shares

\begin{tabular}{lcccccc}
\hline & \multicolumn{3}{c}{ Single-Storey House } & \multicolumn{2}{c}{ Two-Storey House } \\
\cline { 2 - 6 } & Minimum & Maximum & Average & Minimum & Maximum & Average \\
\hline $\begin{array}{l}\text { Construction } \\
\text { cost (Tshs) per } \\
\text { sqm }\end{array}$ & 68,670 & $2,145,450$ & 594,950 & 525,670 & $2,145,450$ & $1,112,270$ \\
Material & & & & & \\
Land & 0.27 & 0.84 & 0.54 & 0.44 & 0.84 & 0.57 \\
$\begin{array}{l}\text { Land to } \\
\text { material cost }\end{array}$ & 0.01 & 0.25 & 0.05 & 0.02 & 0.11 & 0.07 \\
Labour & 0.01 & 0.56 & 0.08 & 0.01 & 0.05 & 0.04 \\
Labour to & 0.07 & 0.22 & 0.14 & 0.08 & 0.23 & 0.17 \\
material cost & 0.10 & 0.43 & 0.27 & 0.10 & 0.48 & 0.32 \\
Other costs & 0.03 & 0.64 & 0.28 & 0.10 & 0.31 & 0.22 \\
\hline
\end{tabular}

\section{Regression Results}

The regression analysis results presented in Table 6 show that the dummy for house type "single-storey" is statistically significant whereby annual construction costs for a single-storey house building are lower by almost $54 \%$ when compared to a twostorey building. Further it can be observed that, an additional sqm of the built space is associated with a $0.4 \%$ lower annual construction cost while an additional bedroom leads to lower annual spending in incremental housing construction cost of about $24 \%$. This is also supported by the observation that each additional year of house construction reduces annual construction cost by about $5 \%$ which increases to $10 \%$ if the period of construction includes the time from plot purchase.

The results for factor intensity show that reducing the amount spent on labour relative to hired capital (physical and financial) by $100 \%$ reduces annual construction cost by almost $5 \%$. A unit increase in capital to material ratio reduces annual construction cost by $26 \%$. The results for both capital to material cost ratio and labour to capital cost ratio are statistically significant suggesting that such ratios are important determinant of incremental housing construction cost.

Further in Figure 3, results for the year effect are presented. However the effect of year seems to be marginal as all year dummies were not significantly associated with construction cost.

Table 6. OLS Regression Analysis Results 


\begin{tabular}{|c|c|c|c|c|c|}
\hline \multirow[t]{2}{*}{ Model } & \multirow{2}{*}{$\begin{array}{c}\boldsymbol{R} \\
0.937\end{array}$} & \multirow{2}{*}{$\begin{array}{c}\begin{array}{c}\boldsymbol{R} \\
\text { Square }\end{array} \\
0.878\end{array}$} & \multicolumn{2}{|c|}{ Adjusted $R$ Square } & \multirow{2}{*}{$\begin{array}{l}\text { Std. Error of } \\
\text { the Estimate }\end{array}$} \\
\hline & & & 0.863 & 0.470 & \\
\hline \multicolumn{6}{|c|}{ Coefficients } \\
\hline & \multicolumn{2}{|c|}{$\begin{array}{l}\text { Unstandardised } \\
\text { Coefficients }\end{array}$} & $\begin{array}{c}\text { Standardised } \\
\text { Coefficients }\end{array}$ & $t$ & Sig. \\
\hline Variable & B & $\begin{array}{l}\text { Std. } \\
\text { Error }\end{array}$ & Beta & & \\
\hline (Constant) & 14.888 & 0.370 & & 40.219 & 0.000 \\
\hline $\begin{array}{l}\text { Property type main } \\
\text { house }\end{array}$ & 0.300 & 0.194 & 0.049 & 1.544 & 0.125 \\
\hline $\begin{array}{l}\text { House type single- } \\
\text { storey }\end{array}$ & (0.773) & 0.121 & $(0.254)$ & (6.402) & 0.000 \\
\hline $\begin{array}{l}\text { Size of built-up space } \\
\text { (sqm) }\end{array}$ & $(0.004)$ & 0.000 & (0.349) & (8.964) & 0.000 \\
\hline $\begin{array}{l}\text { Number of } \\
\text { bedrooms }\end{array}$ & $(0.278)$ & 0.066 & (0.173) & $(4.193)$ & 0.000 \\
\hline $\begin{array}{l}\text { Duration to home } \\
\text { ownership }\end{array}$ & (0.109) & 0.011 & (0.495) & (9.505) & 0.000 \\
\hline $\begin{array}{l}\text { Duration of housing } \\
\text { construction in years }\end{array}$ & $(0.054)$ & 0.012 & $(0.247)$ & (4.363) & 0.000 \\
\hline $\begin{array}{l}\text { Labour to material } \\
\text { cost }\end{array}$ & (0.078) & 0.208 & $(0.011)$ & (0.377) & 0.707 \\
\hline $\begin{array}{l}\text { Labour to capital } \\
\text { cost }\end{array}$ & $(0.050)$ & 0.012 & $(0.145)$ & $(4.045)$ & 0.000 \\
\hline $\begin{array}{l}\text { Capital to material } \\
\text { cost }\end{array}$ & $(0.261)$ & 0.117 & $(0.086)$ & (2.237) & 0.027 \\
\hline 2000 & 0.115 & 0.254 & 0.019 & 0.452 & 0.652 \\
\hline 2002 & 0.172 & 0.236 & 0.036 & 0.729 & 0.467 \\
\hline 2004 & 0.085 & 0.232 & 0.018 & 0.365 & 0.716 \\
\hline 2006 & 0.045 & 0.231 & 0.010 & 0.193 & 0.847 \\
\hline 2007 & 0.146 & 0.246 & 0.028 & 0.591 & 0.555 \\
\hline 2008 & $(0.065)$ & 0.233 & $(0.016)$ & (0.281) & 0.779 \\
\hline 2009 & $(0.135)$ & 0.234 & $(0.032)$ & (0.579) & 0.564 \\
\hline 2010 & $(0.147)$ & 0.234 & $(0.036)$ & $(0.631)$ & 0.529 \\
\hline 2011 & $(0.073)$ & 0.238 & $(0.017)$ & (0.307) & 0.759 \\
\hline 2012 & $(0.032)$ & 0.237 & $(0.008)$ & $(0.134)$ & 0.893 \\
\hline 2013 & 0.032 & 0.240 & 0.007 & 0.133 & 0.894 \\
\hline
\end{tabular}

Notes: Dependent variable: Natural log of annual construction cost per sqm 


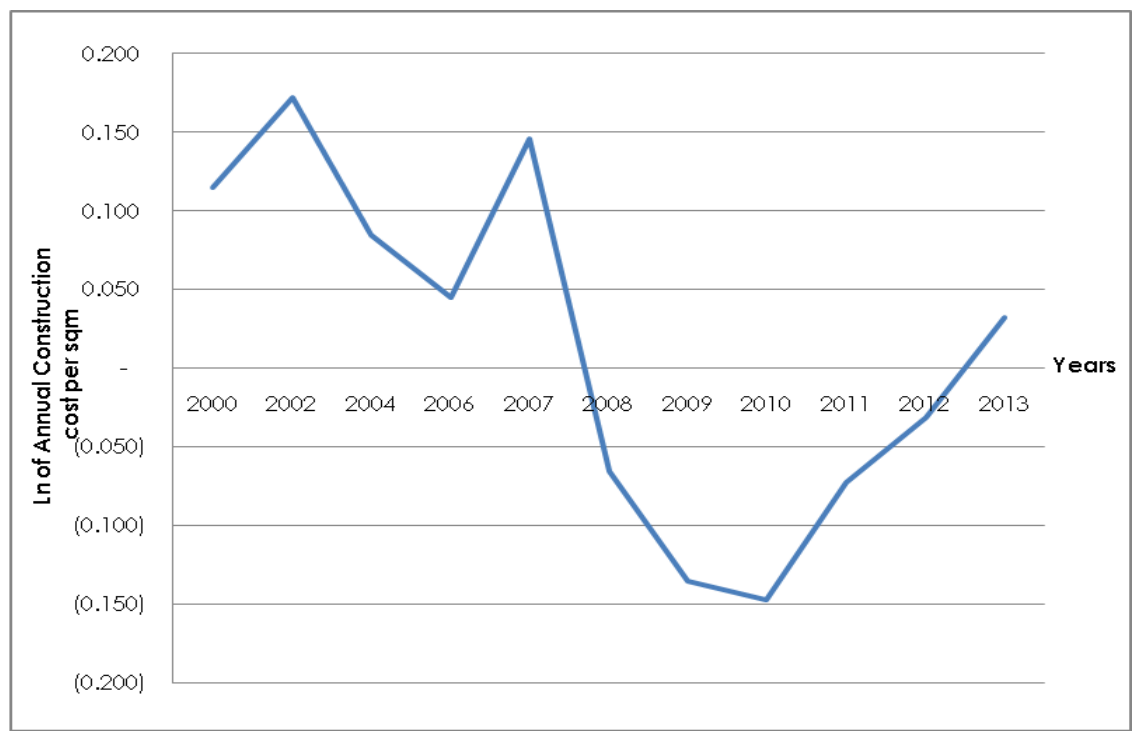

Figure 3. Annual Variation in Incremental Construction Cost

\section{DISCUSSION OF THE FINDINGS}

From the above analysis, four clear perspectives emerge with respect to incremental housing construction in Dar es Salaam. Firstly, annual expenditure on incremental construction activities tends to decline with the size of the project. Secondly, the longer the period under which a specific house is under construction the smaller are the annual increments in costs required to realise one's dream home. When this second perspective is combined with the first it is clear that the nature of incremental construction means that, the longer one constructs his/her house the bigger it becomes and the larger is the cost spread effect. Thirdly, although incremental housing cost can significantly be reduced by employing more physical and financial capital, such costs will be reduced the greatest if expenditure on capital is increased relatively faster than materials. It seems incremental construction enjoys a capital advantage with increasing material consumption. Lastly, the longer it takes to complete a house, the lower are the annual construction costs of incremental housing. In this regard incremental housing provides a cushion against anticipated annual variation in economic variables.

Incremental housing project tends to start small and grow over time hence cannot enjoy economies of scale within the traditional context of the term rather "economies of time". The declining annual cost as the house "grows" can be attributed to time of construction and the higher probability to access sources of materials which are often cheaper than the formal ones. These informal sources can have a significant cost-reduction effect on incremental housing. Also, with time the owner can significantly provide own labour in the construction process. There is sufficient evidence in many developing countries that owners and their families are often involved in brick making, transporting the materials and even the 
masonry or carpentry works (Magigi and Majani, 2006; Majale, Tipple and French, 2012). Given the difficulties in estimating these implicit costs, the annual construction cost reported may be lower. Therefore the cost reduction effect of size in incremental construction is a result of opportunities that are associated with lapse of time rather than economies of scale.

Changes in economic environment into which houses are constructed also entail more opportunities in order to lengthen the time of implementation. Time can allow for a thorough search for cheaper plots, efficient production techniques and efficient labour utilisation. One of the challenges not considered in this study is the effect of lower cost on the quality of housing provided under the incremental approach. The study assumes that construction materials are uniform across housing units thus allowing comparison across cost elements only.

Not so common in incremental construction is the role of housing finance. The effect of loan capital is implicit in the capital to material ratio and the labour to capital ratio. It has been observed that, incremental housing projects that enjoy the greatest cost-saving advantage are those having a larger capital cost component relative to materials. For practical purposes it is not clear how the two are related but by increasing capital on a fixed amount of materials, incremental housing will be cheaper than spending more labour on fixed amount of capital or labour on materials. This observation suggests that incremental builders can enjoy a cost reduction by having access to loan and spending more on hiring capital equipment. Although loan capital increases cost, it has some material cost-saving advantage probably due to reduction in material waste as finances are more instant allowing discounting pricing for purchasing large quantities and immediate use. Capital has some labour cost-saving advantages mainly from labour substitution.

Despite being one among the methods relied-upon by low-income household to access housing, incremental housing is challenged by lack of policy which would have facilitated access to low cost finance and a coherent structure of the type and quality of buildings. Without such a policy, the approach hardly provides housing of durable materials to exceed one generation without major repairs which may be equivalent to adding another house. The vicious cycle of poverty is highly magnified by lack of appropriate policies for the provision of incremental housing allowing for the continued urban sprawl of the same lowquality housing.

\section{CONCLUSION}

Construction cost in incremental owner-built housing is primarily determined by the length of time for which such construction process takes place. The longer the construction period the lower are the annual construction costs. To fully benefit from incremental construction, owner-builders have to purchase bigger plots and enlarge their houses incrementally. The largest cost-saving benefits accrue to owner builders if the proportion of physical and financial capital increases faster relative to materials in different phases of the projects. The observations in this study culminate to the conclusion that the adoption of incremental approaches is a matter of necessity than an option. However, because the approach is neither standardised nor regulated, there are a lot of wastes which emanate from lack of 
proper initial plans. The owner-builders often do not consider the opportunity cost of time and the labour lost in supervising the construction process. However, since the opportunity cost of time is presumed to vary across countries, the incremental housing approach is preferred in developing countries where the opportunity cost of labour is lower than in developed countries. Massive construction of housing units could be the most economical way to provide housing provided adequate policies are in place that would facilitate the internalisation of economies of scale. Since developing countries lack appropriate policies to attract massive developerbuilt housing, the incremental approach is the only viable option. Developing countries are therefore, argued to develop appropriate housing finance policies and guide incremental housing material quality in order to reduce the intergenerational wastes associated with the approach.

\section{ACKNOWLEDGEMENT}

This research project would not have been possible without the concerted financial support of Swedish International Development Agency research project which allowed Ardhi University (ARU) to support this project. Special gratitude to ARU for commendable work on the overall management of the project and for providing us with a good environment and facilities to complete this project.

\section{REFERENCES}

Abdel-Kader, N. and Ettouney, S. (2010). Incremental housing development 2010: Lowering the cost, lowering-not the standards: A conceptual framework. Paper presented at the World Congress on Housing. Santander, Spain, 26-29 October.

Alagbe, O., Adewale, B. and Alagbe, T. (2014). Assessment of promotions of compressed stabilized laterite bricks in predicting its acceptability for housing in Lagos State, Nigeria. Proceedings: CIB W107 2014 International Conference. Lagos, Nigeria: International Council for Building (CIB), 716-723.

Albuquerque, A. (2012). Rights to the land under your home. In S. Anderson and R. Beck (eds.). The BIG IDEA: Global Spread of Affordable Housing. Arlington, VA: Next Billion and Ashoka Full Economic Citizenship, 16-18.

Arvanitis, Y. (2013). African housing dynamics: Lessons from the Kenyan market. Africa Economic Brief, 4(3): 1-12.

Beattie, N., Mayer, C. and Yildirim, A.B. (2010). Incremental housing: Solutions to meet the global urban housing challenge. Proceedings: UN World Urban Forum. Rio de Janeiro: Global University Consortium - SIGUS-MIT, 1-23.

Beck, R. (2012). Global spread of affordable housing: Introduction. In S. Anderson and R. Beck (eds.). The BIG IDEA: Global Spread of Affordable Housing. Arlington, VA: Next Billion and Ashoka Full Economic Citizenship, 9-11.

Bisiaux, R. (2014). Rethinking informal housing and land ownership debates from local actors' perceptions: A sociological understanding of the failed eviction of Thapathali informal settlement, Kathmandu. In A.M. Garland (ed.). Innovation in Urban Development: Incremental Housing, Big Data, and Gender. Washington DC: Wilson Center, 57-86. 
Boamah, N. (2010). Housing affordability in Ghana: A focus on Kumasi and Tamale. Ethiopian Journal of Environmental Studies and Management, 3(3): 1-11.

Carliner, M. (2003). New home cost components. Housing Economics, March. Available at: http://www.michaelcarliner.com/files/HE0303-MSC-Cost.pdf [Accessed on 15 January 2015].

Drummond, R., Chongo, B. and Mususa, P. (2013). Scoping Study: Overview of the Housing Finance Sector in Zambia. Pretoria, South Africa: FinMark Trust and Centre for Affordable Housing Finance in Africa.

Gattoni, G. (2009). A Case for the Incremental Housing Process in Sites-andServices Programs and Comments on a New Initiative in Guyana. Washington DC: Inter-American Development Bank.

Giddings, S.W. (2007). Housing Challenges and Opportunities in Sub-Saharan Africa. Washington DC: International Housing Coalition.

Greene, M. and Edwardo, R. (2008). Incremental construction: A strategy to facilitate access to housing. Environment and Urbanization, 20(1): 89-108. doi: $10.1177 / 0956247808089150$.

Harper, C., Portugal, V. and Shaikley, L. (2011). Incremental expansion: Examining user-initiated transformations in government housing in Manaus. In A.M. Garland (ed.). Innovation in Urban Development: Incremental Housing, Big Data, and Gender. Washington DC: Wilson Center, 7-33.

Hoek-Smit, M.C. (1998). Housing Finance in Bangladesh: Improving Access to Housing Finance by Middle and Lower Income Groups. Dhaka: The Government of Bangladesh and UNDP/UNCHS (Habitat).

Kironde, L. (1995). Access to land by the urban poor in Tanzania: Some findings from Dar es Salaam. Environment and Urbanization, 7(1): 77-95. doi: $10.1177 / 095624789500700111$.

Lim, G.C. (1987). Housing policies for the urban poor in developing countries. Journal of the American Planning Association, 53(2): 176-185. doi: $10.1080 / 01944368708976650$.

Magigi, W. and Majani, B.B. (2006). Housing themselves in informal settlements: A challenge to processes, land vulnerability and poverty reduction in Tanzania. Issues on Urban Growth: Customary Title and Informal Settlements. Accra, Ghana: International Federation of Surveyors (FIG), 24.

Majale, M., Tipple, G. and French, M. (2012). Affordable Land and Housing in Africa. Nairobi: UN-Habitat.

Makoba, N. (2009). Housing typology for low income earners in Dar es Salaam: Seeking affordability. Journal of Building and Land Development, 16(1-2): $15-29$.

Malpezzi, S. and Sa-Aadu, J. (1996). What have African housing policies wrought? Real Estate Economics, 24(2): 133-160. doi: 10.1111/1540-6229.00684.

Maly, E., Kondo, T. and Shiozaki, Y. (2012). An increamentally expandable core house for disaster reconstruction: Tow cases of Yogakyarta Indonesia after the Central Java earthquake. Memoirs of the Graduate School of Engineering and System Informatics Kobe University, 4(1): 1-7.

Mayank, H., Nanavaty, M., Chakraborty, S.D., Mitra, S. and Limaye, A. (2012). Affordable Housing in India: An Inclusive Approach to Sheltering the Bottom of the Pyramid. Mumbai, India: Jones Lang Lasalle.

Mbyopo, G.M. (1993). Review of Town Planning and Urban Development Programmes. Dar es Salaam, Tanzania: Ardhi University.

128/PENERBIT UNIVERSITI SAINS MALAYSIA 
Mehta, R. and Bridwell, L. (2005). Innovative construction technology for affordable mass housing in Tanzania, East Africa. Construction Management and Economics, 23(1): 69-79. doi: 10.1080/0144619042000287769.

MKURABITA. (2008). Property and Business Formalisation Program: Property Formalisation Reform Outlines and Packages for Tanzania Mainland. Vol. 2. Dar es salaam, Tanzania: MKURABITA Management Unit.

Moavenzadeh, F. and Rossow, J.A. (1975). The Construction Industry in Developing Countries: Technology Adaptation Programme. Massachusetts: Massachusetts Institute of Technology.

Monkkonen, P. (2009). The housing transition in Mexico: Local impacts of national policy. PhD diss. University of California.

Mujobu Moyo, R., Simson, A.J. and de Mevius, F.-X. (2010). Attaining Middle Income Status, Tanzania: Growth and Structural Transformation Required to Reach Middle Income Status by 2025. Dar es Salaam, Tanzania: President's Office Planning Commission (POPC).

Mukhija, V. (2014). The value of incremental development and design in affordable housing. Cityscape: A Journal of Policy Development and Research, 16(2): 11-20.

Mumtaz, B. (1995). Meeting the demand for housing: A model for establishing affordability parameters. Working Paper No. 73. London: Development Planning Unit, University College London.

Mwiga, B.G. (2011). Evaluating the Effectiveness of the Regulatory Framework in Providing Planned Land in Urban Areas: The Case of Dar es Salaam City 20,000 Plot Project, Tanzania. Enschede, The Netherland: ITC Faculty, University of Twente.

Nakamura, S. (2014). Tenure formalization, tenure security and housing investment: The relevance of self-help housing in India reexamined. In A.M. Garland (ed.). Innovation in Urban Development: Incremental Housing, Big Data and Gender. Washington DC: Wilson Center, 87-107.

National Housing Cooperation (NHC)-Tanzania. (2010). Strategic Plan for 2010/112014/15. Dodoma, Tanzania: NHC.

Neves, S.O. and Amado, M. (2014). Incremental housing as a method to the sustainable habitat. Proceedings: 30th International PLEA Conference. Ahmedabad, India: CEPT University Press.

New Zealand Productivity Commission (NPC). (2012). Housing Affordability Inquiry. South Wales: NPC. Available at: http://www.productivity.govt.nz/sites/ default/files/Final\%20Housing\%20Affordability\%20Report_0_0.pdf.

Nguluma, H.M. (2003). Housing Themselves: Transformations, Modernisation and Spatial Qualities in Informal Settlements in Dar es Salaam, Tanzania. Stockholm: Royal Institute of Technology.

Nohn, M. and Bhatt, B.B. (2014). How to assess security of tenure and emulate mortgages for financing semi-formal homes: Lessons from Mahila Housing SEWA Trust. WIEGO Technical Brief No. 8. Cambridge, USA: Women in Informal Employment: Globalizing and Organizing (WIEGO).

Oikarinen, E. (2009). Dynamic linkages between housing and lot prices: Empirical evidence from Helsinki. Discussion Paper No. 53. Finland: Aboa Centre for Economics. Available at: http://www.ace-economics.fi/kuvat/dp53.pdf. 
Samaranayake, S. (2012). In the race for affordable housing: Who has the head start? In S. Anderson and R. Beck (eds.). The BIG IDEA: Global Spread of Affordable Housing. Arlington, VA: Next Billion and Ashoka Full Economic Citizenship, 65-72.

Schmidt, S. (2006). Housing solutions serving low-income populations: A framework for action. World Urban Forum III. Vancouver: International Housing Coalition $(\mathrm{IHC})$.

Scott, M. (2012). Beyond four walls. In S. Anderson and R. Beck (eds.). The BIG IDEA: Global Spread of Affordable Housing. Arlington, VA: Next Billion and Ashoka Full Economic Citizenship, 76-81.

ShoreBank International. (2011). Fesibility Study on Developing a Social Housing Programme at Shelter Afrique. Nairobi: Shelter Afrique.

Siddiqui, T. (2005). Incremental Housing Development Scheme (Pakistan): An Innovative and Successful Scheme for Sheltering the Urban Poor. Karachi: SAIBAN Action Research for Shelter.

Taylor, H. (2012). New Construction Cost Breakdown: Special Study for HousingEconomics.com. Washington DC: National Association of Home Builders. Available at: https://www.nahb.org/ /media/Sites/NAHB/ Unmapped/PDF/A-M/costofconstructionFINAL_20111104031133.ashx?la=en.

Turner, J.C. (1967). Barriers and channels for housing development in modernizing countries. Journal of the American Institute of Planners, 33(3): 167-181. doi: 10.1080/01944366708977912. doi: 10.1080/01944366708977912.

UN-Habitat. (2010). Annual Report. Nairobi: UN-Habitat.

- (2008). Housing for All: The Challenges of Affordability, Accessibility and Sustainability. Nairobi: UN-Habitat.

van Winssen, I. (2014). Slum rehab flats: A happy living? The subjective well-being of rehabilitated residents and the impact of the slum plan in Mumbai. In A.M. Garland (ed.). Innovation in Urban Development: Incremental Housing, Big Data, and Gender. Washington DC: Wilson Center, 108-126.

Wakely, P. (2014). Urban public housing strategies in developing countries: Whence and whither paradigms, policies, programmes and projects. DPU60 Working Paper Series: Reflections No. 163/60. London: Development Planning Unit, University College London.

Wells, J. (2001). The construction industry in the twentyfirst century: Its image, employment prospects and skill requirements. In Tripartite Meeting on the Construction Industry in the Twenty-first Century: Its Image, Employment Prospects and Skill Requirements. Geneva: International Labour Organisation.

World Bank. (2015a). World Bank national accounts data, and OECD national accounts data files. GNI per Capita, Atlas Method (Current US\$). Washington DC: World Bank. Available at: http://data.worldbank. org/indicator/NY.GNP.PCAP.CD/countries [Accessed on 15 July 2015].

. (2015b). Urban Population (\% of Total). Washington DC: World Bank. Available at: http://data.worldbank.org/indicator/SP.URB.TOTL.IN.ZS [Accessed on 17 June 2015]. 